\title{
Anti-inflammatory and Anti-arthritic Potentials of Maesa Montana Roots
}

\author{
Sanjida SHARMIN*, Rabeya Gazi JHUMA, \\ Sanjida ISLAM and Riniara KHATUN
}

Department of Pharmacy, International Islamic University Chittagong, Chittagong 4318, Bangladesh

("Corresponding author's e-mail: sharmin.shanjida@gmail.com)

Received: 27 February 2020, Revised: 13 March 2021, Accepted: 20 March 2021

\begin{abstract}
Maesa Montana is a flowering plant of the Myrsinaceae family, which is locally known as ramjani. The current study aimed to evaluate the in-vitro anti-arthritic and anti-inflammatory activities of the root extract of this plant. The anti-inflammatory performances were measured by the hindrance of egg white denaturation, and anti-arthritic activity was investigated by Bovine serum protein. In the antiinflammatory activity test, the methanolic root extract of this plant showed $69.29 \pm 1.19 \%$ of inhibition at a concentration of $1000 \mu \mathrm{g} / \mathrm{mL}$ and standard drug exhibited $90.11 \pm 1.45 \%$ of inhibition at the same concentration. Furthermore, in the anti-arthritic activity test, the extract demonstrated $68.18 \pm 1.34 \%$ of inhibition at a concentration of $1000 \mu \mathrm{g} / \mathrm{mL}$ whereas the standard diclofenac drug showed $90.65 \pm 1.19 \%$ of inhibition at the same concentration. These results revealed that the root extract of this plant possesses significant anti-arthritic and anti-inflammatory activities based on the inhibition of BSA and protein denaturation.
\end{abstract}

Keywords: Maesa Montana, Anti-arthritic, Anti-inflammatory, Protein denaturation

\section{HIGHLIGHTS}

\section{Introduction}

The tradition of using plants to treat human diseases is as old as the evolution of human civilization itself. From the beginning of human civilization, medicinal plants have been playing an important role in the human welfare [1]. A medicinal plant can possibly be defined as the commonly used plants for treating and preventing different types of ailments and disorders. Plants, employing favorable pharmacological impacts on physical body are usually titled as "Medicinal plants." It can now be reached to the conclusion that plants, which normally integrate and possess some secondary metabolites, similar to tannins, alkaloids, glycosides and comprise minerals as well as vitamins, have therapeutic properties [2].

The popularity of the traditional medicine has been increasing in the developing countries as well as in the developed countries due to the fact that modern medicine failed to provide successful treatment for different chronic diseases, where there is an advent of the resistant variants of bacteria and parasites. The adverse side effects of synthetic medicines and their rising costs have also led to an increased interest on alternative treatments among the people [3].

Inflammation is a natural response of the body from an infection or damage of the tissue, which is manifested by hot, swollen pain and redness of the area adjacent inflammation. The causative agents of inflammation include toxic compounds or infection due to microbial agents. The defense mechanism of the body is to try to inactivate or kill the invading pathogen to eliminate the irritating substrates and repair 
the damaged tissues [4]. Non-steroidal anti-inflammatory drugs are commonly used to treat inflammations, but they have different unfavorable effects, including gastric irritation that may lead to gastric ulcers. As the plant kingdom serves as a source of discovering new compounds, some of them may have significant anti-inflammatory effects without major side effects [5].

The term arthritis means any disorder that especially affects the joints. Joint pain, swelling, stiffness, inability to move freely are some of the most common arthritis symptoms [6,7]. The symptomatic relief of this problem is generally achieved by using non-steroidal anti-inflammatory drugs or anti-rheumatic agents. Plant extracts were traditionally used for reducing arthritic pain [8].

Maesa Montana is a big shrub, having a height of $2-3 \mathrm{~m}$. The leaves are elliptic, rectangle or spear shaped and in rare cases can be roughly ellipsoid. Flowers are generally of white color, bell-shaped, ellipsoid petals, longer than a tube, with an entire border or toothed, rounded tip. The blooming period of this plant is from February to April $[9,10]$.

\section{Materials and methods}

\section{Plant material collection}

The fresh roots of the plant M. Montana were collected in the month of January 2019 from the division of Chittagong, Bangladesh. After collecting, a professor of botany department of Chittagong University named Dr. Sheikh Bakhtiar Uddin identified the roots.

\section{Plant extraction procedure}

Plant materials were cut into small pieces for grinding. The small pieces of roots were ground into a coarse powder using a grinder. About $500 \mathrm{gm}$ of the powder was soaked in a cleaned amber glass reagent bottle $(5 \mathrm{~L})$ using $1.6 \mathrm{~L}$ of methanol. The bottle was airtight and kept for 7 days at the optimum temperature with shaking at a regular interval and then filtered firstly through a cotton plug and then through a filter paper (pore size $110 \mathrm{~mm}$ ). The solvent was evaporated with a water bath to yield a solid mass. The bulk of the extract collected was $23 \mathrm{gm}$. The prepared extract was kept in the refrigerator to prevent microbial contamination.

\section{Anti-Inflammatory activity test}

The anti-inflammatory test was performed following the technique described by Sakat et al. [11]; Leelaprakash and Dass [12]. The egg was made to use for the source of albumin and was reconstituted as a $5 \% \mathrm{v} / \mathrm{v}$ aqueous solution with iso-saline. To prepare the sample solution, $1 \mathrm{mg}$ root extract was mixed with $10 \mathrm{~mL}$ methanol. For preparing the standard solution, $10 \mathrm{mg}$ diclofenac sodium was taken and mixed with $4 \mathrm{~mL}$ methanol.

For the preparation of test solution, egg albumin $(0.2 \mathrm{~mL})$, phosphate buffered having a $\mathrm{pH}$ of 6.4 $(2.8 \mathrm{~mL})$ and varying concentrations of the test extract $(2 \mathrm{~mL})$ was taken in different test tubes. The standard solution was prepared in a similar manner using diclofenac sodium instead of the extract. Same volume of distilled water was used as a control. Then, the all the test tubes were incubated at around 37 ${ }^{\circ} \mathrm{C}$ in an incubator for a period of $15 \mathrm{~min}$. Then, it was heated for $5 \mathrm{~min}$ at a temperature of $70{ }^{\circ} \mathrm{C}$. After cooling, the absorbance of the test tubes were measured at $660 \mathrm{~nm}$ against the blank [13]. The percentage inhibition of protein denaturation was calculated by using the following formula:

$\%$ inhibition $=[\mathrm{Vc}-\mathrm{Vt}] \mathrm{Vc} \times 100 \%$

where, $\mathrm{Vt}=$ Absorbance of test sample, $\mathrm{Vc}=$ Absorbance of control.

Fifty Percent of albumin denaturation of the extract was determined from the dose-response curve.

\section{Anti-arthritic activity}

Protein denaturation inhibition by using BSA was determined following the procedure narrated by Pavithra et al. [9]; Kumari et al. [14] . 
$5 \% \mathrm{w} / \mathrm{v}$ BSA solution was made by dissolving $5 \mathrm{gm} \mathrm{BSA}$ in $100 \mathrm{~mL}$ distilled water. In the case of preparing the phosphate buffer, $0.45 \mathrm{gm} \mathrm{NaH} \mathrm{PO}_{4}$ and $0.887 \mathrm{gm} \mathrm{Na}_{2} \mathrm{HPO}_{4}$ were taken in a beaker. Then up to $100 \mathrm{~mL}$ distilled water was added to prepare the solution. The $\mathrm{pH} 6.3$ was adjusted by using $1 \mathrm{~N}$ $\mathrm{HCl}$. Here, $10 \mathrm{mg}$ of the extract was liquefied in $10 \mathrm{~mL}$ of distilled water to prepare a stock solution with $1 \mathrm{mg} / \mathrm{mL}$ concentration. Then, the test solutions were prepared by diluting the stock solutions $(1000,500$, $250,125,62.5$ and $31.75 \mathrm{ug} / \mathrm{mL})$. The standard solution was prepared in a similar manner using the diclofenac sodium. The test control solution was prepared by dissolving $0.2 \mathrm{~mL}$ of BSA and $2 \mathrm{~mL}$ of distilled water in $2.8 \mathrm{~mL}$ of phosphate buffer. The test solution was prepared using $2 \mathrm{~mL}$ of extract or standard solution of varying concentration, $2.8 \mathrm{~mL}$ of phosphate buffer and $0.2 \mathrm{~mL}$ BSA solution, then the product control was prepared by dissolving $2 \mathrm{~mL}$ of extract or standard solution of varying concentration, $2.8 \mathrm{~mL}$ of phosphate buffer and $0.2 \mathrm{~mL}$ of distilled water. All the test tubes mixtures were kept at $37^{\circ} \mathrm{C}$ for around $30 \mathrm{~min}$ and then again incubated at $57^{\circ} \mathrm{C}$ for $5 \mathrm{~min}$. The absorbance was taken at $660 \mathrm{~nm}$. The following equation can determine the anti-arthritic activity of the plant extract:

$=100-\frac{\text { Absorbaceoftestsolution-Absorbanceofproductcontrol }}{\text { Absorbanceofcontrol }} \times 100 \%$.

\section{Results and discussion}

In the current study, the methanolic extract of M. Montana showed mean inhibition of protein denaturation of around 42.72, 48.82, 56.35, 66.52, 79.76, $90.18 \%$ for the doses of 78.115, 156.25, 312.5, 625,1250 and $2500 \mu \mathrm{g} / \mathrm{mL}$, respectively whereas for the standard diclofenac sodium, it was found around 38.94, 46.11, 53.64, 58.88, 62.56 and $69.29 \%$ for the same doses respectively (Table 1 and Figure 1). Here, the $\mathrm{IC}_{50}$ value of the standard was 64.35 and for the sample, it was 351.90. The anti-inflammatory assay was performed by using egg albumin. From this experiment, it was noticed that the root extract had a moderate anti-inflammatory effect.

Table 1 Anti-inflammatory results of the methanolic extract of M. Montana and standard diclofenac powder.

\begin{tabular}{ccc}
\hline Concentration & $\begin{array}{c}\text { Sample } \\
\text { \% inhibition }\end{array}$ & $\begin{array}{c}\text { Standard } \\
\text { \% inhibition }\end{array}$ \\
\hline 78.115 & $38.35 \pm 1.09$ & $42.72 \pm 1.67$ \\
156.25 & $46.35 \pm 1.11$ & $48.82 \pm 1.02$ \\
312.50 & $53.64 \pm 0.79$ & $56.35 \pm 1.36$ \\
625 & $58.88 \pm 0.48$ & $66.52 \pm 1.06$ \\
1250 & $62.56 \pm 1.03$ & $79.76 \pm 0.58$ \\
2500 & $69.29 \pm 1.19$ & $90.11 \pm 1.45$ \\
\hline
\end{tabular}




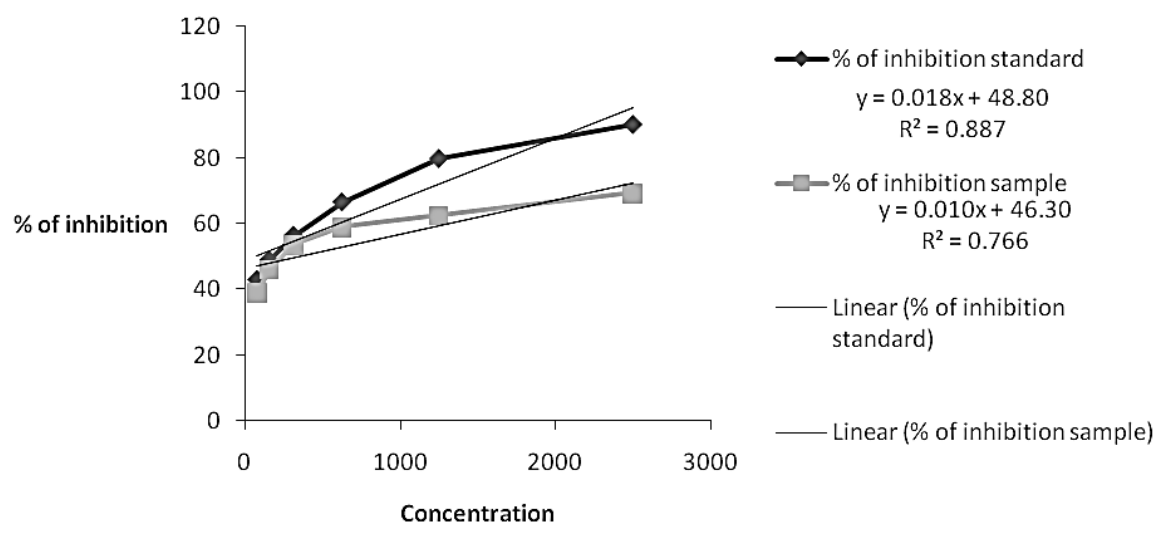

Figure 1 Percent of protein denaturation inhibition of M. Montana root extract and diclofenac sodium (standard).

The extract showed significant anti-arthritic activities with $20.77,29.78,37.87,51.51,56.06$ and $68.18 \%$ of inhibition according to the concentration of $31.75,62.75,125,250,500$ and $1000 \mu \mathrm{g} / \mathrm{mL}$; where the standard drug showed 38.33, 50.44, 58.09, 70.87, 80.56 and $90.65 \%$ of inhibition with their belonging concentrations (Table 2 and Figure 2). The anti-arthritis properties of these extracts indicated the possibility of the presence of alkaloids, flavonoids and steroid compounds in the methanolic extract [15]. Though it had a moderate activity, it could be a possible source of anti-arthritic drugs from further research studies.

Table 2 Anti-arthritic result of methanolic extract of M. Montana.

\begin{tabular}{ccc}
\hline Concentration $(\boldsymbol{\mu g} / \mathbf{m L})$ & $\begin{array}{c}\text { Sample } \\
\text { \% inhibition }\end{array}$ & $\begin{array}{c}\text { Standard } \\
\text { \% inhibition }\end{array}$ \\
\hline 31.75 & $20.77 \pm 1.19$ & $38.33 \pm 1.22$ \\
62.75 & $29.78 \pm 0.67$ & $50.44 \pm 1.88$ \\
125 & $37.87 \pm 1.08$ & $58.09 \pm 1.67$ \\
250 & $51.51 \pm 1.20$ & $70.87 \pm 1.12$ \\
500 & $56.06 \pm 0.98$ & $80.56 \pm 0.56$ \\
1000 & $68.18 \pm 1.34$ & $90.65 \pm 1.19$ \\
\hline
\end{tabular}




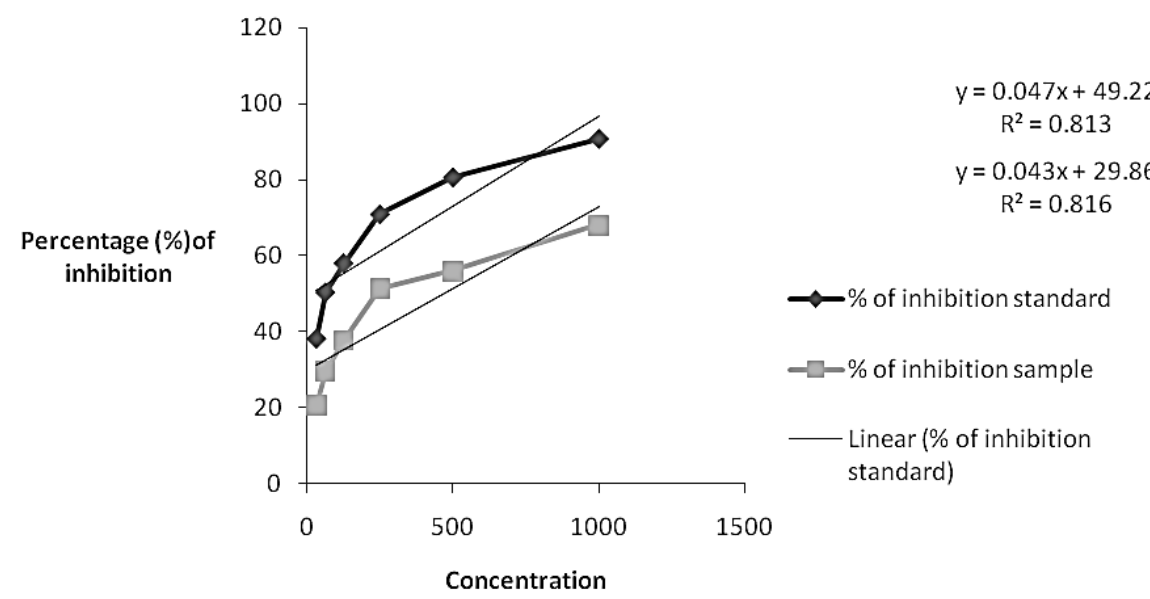

Figure 2 Percent of BSA denaturation inhibition of M. Montana root extract and diclofenac sodium (standard).

\section{Conclusions}

It can be concluded that this well-acquainted study appraised moderate in vitro anti-arthritic and anti-inflammatory features of the methanolic extract of $M$. Montana at different doses. However, all pharmacological profiles have not been investigated for this plant. Further investigations using advanced techniques and animal models could be attained through careful and systemic schemes.

\section{Acknowledgements}

The authors are thankful to the Department of Pharmacy, IIUC, Bangladesh, for giving the financial support and for allowing the authors to use the facilities to perform the current research activities smoothly.

\section{References}

[1] AG Atanasov, B Waltenberger, EM Pferschy-Wenzig, T Linder, C Wawrosch, P Uhrin, V Temml, L Wang, S Schwaiger, EH Heiss and JM Rollinger. Discovery and resupply of pharmacologically active plant-derived natural products: A review. Biotechnol. Adv. 2015; 33, 1582-614.

[2] Z Morshed. 2018, Phytochemical and biological screening of methanol extract of Maesa Montana (Myrsinaceae) leave. Bachelor Dissertation. BRAC University, Dhaka, Bangladesh.

[3] F Firenzuoli and L Gori. Herbal medicine today: Clinical and research issues. Evidence-based Compl. Alternative Med. 2007; 4, 37-40.

[4] The Editors of Encyclopaedia Britannica, Available at: https://www.britannica.com/science/ inflammation, assessed March 2021.

[5] L Chen, H Deng, H Cui, J Fang, Z Zuo, J Deng, Y Li, X Wang and L Zhoa. Inflammatory responses and inflammation-associated diseases in organs. Oncotarget 2018; 9, 7204-18.

[6] CV Tehlirian and JM Bathon. Rheumatoid arthritis. In: JH Klippel, JH Stone, LJ Crofford and PH White (Eds.). Primer on the rheumatic diseases. Springer, New York, 2010, p. 114-41.

[7] DP Orchanian. Rheumatic diseases. In: B Atchison and DP Dirette (Eds.). Conditions in occupational therapy. Wolters Kluwer/Lippincott Williams \& Wilkins, Philadelphia, 2012, p. 225.

[8] S Sharmin, T Sifat, A Azad, A Reza, MK Islam and MA Sayeed. Preliminary phytopharmacological investigation of Duabanga grandiflora (Roxb. ex DC.) Walpers. Bangladesh pharmaceut. J. 2020; 23, 54-60. 
http://wjst.wu.ac.th

[9] Trees and Shrubs Online, Available at: https://treesandshrubsonline.org/articles/maesa/maesamontana, accessed March 2021.

[10] Flora of China Editorial Committee. Flora of China. China, 2018, p. 3.

[11] SS Sakat, AR Juvekar and MN Gambhire. In-vitro antioxidant and anti-inflammatory activity of methanol extract of Oxalis corniculata Linn. Int. J. Pharm. Pharmaceut. Sci. 2010; 2, 146-55.

[12] G Leelaprakash and SM Dass. In vitro anti-inflammatory activity of methanol extract of Enicostemma axillare. Int. J. Drug Dev. Res. 2011; 3,189-96.

[13] S Chandra, P Dey and S Bhattacharya. Preliminary in vitro assessment of anti-inflammatory property of Mikania scandens flower extract. J. Adv. Pharm. Educ. Res. 2012; 2, 25-31.

[14] CS Kumari, N Yasmin, MR Hussain and M Babuselvam. In vitro anti-inflammatory and antiarthritic property of Rhizopora mucronata leaves. Int. J. Pharm. Sci. Res. 2015; 6, 482-5.

[15] AA Kamble, ND Khan, ZH Khan, SM Mular and S Sohail. In vitro anti-arthritic activity of vitex negundo and punica granatum. Res. J. Pharm. Sci. 2017; 6, 5-7. 